\title{
Interview with Ge Gan-ru
}

$\mathrm{T}$ his interview is with the person rightly called China's first “avant-garde” composer, Ge Gan-ru. The honor is due to his 1983 composition for solo cello, Yi Feng (Lost Style), which grew out of his in-depth analysis of how Western and Chinese music differ in their core presumptions about pitch, rhythm, timbre, and dynamics. A summary of that analysis is an important feature of this interview. Among other works discussed are his Wrong, Wrong, Wrong! for Voice, self-accompanied by a Toy Orchestra (2006), and his Fifth String Quartet (2007), titled Fall of Baghdad. Interview with Ge Gan-ru for ICONI, conducted by Dr. Edward Green.

Это интервью с человеком, которого справедливо называют первым китайским «авангардным» композитором, Гэ Ган-ру. Он получил известность в 1983 году благодаря композиции для виолончели соло «Yі Feng» («Потерянный стиль»), которая выросла из его глубокого понимания того, как западная и китайская музыка отличаются своими представлениями о звуковысотности, ритме, тембре, динамике. Сущность этого анализа составляет важную особенность данного интервью. Среди других обсуждаемых работ - его «Неправильно, неправильно, неправильно!» для голоса в сопровождении игрушечного оркестра (2006), а также Пятый струнный квартет (2007), названный «Падение Багдада». Интервью с Гэ Ган-ру для ИКОНИ проведено доктором Эдвардом ГриHOM.

Edward Green: You have been called the first "avant-garde" composer of China. How did that come to be?

Ge Gan-ru: This is due to my composition Yi Feng (Lost Style) for solo cello, written in 1983.

Before composing Yi Feng, I tried very hard to find my own musical language. I wrote music in different styles including twelve-tone music. But none of them made me feel comfortable, or original original in the sense of having its "origin" in my own sincere feelings. Not "original"

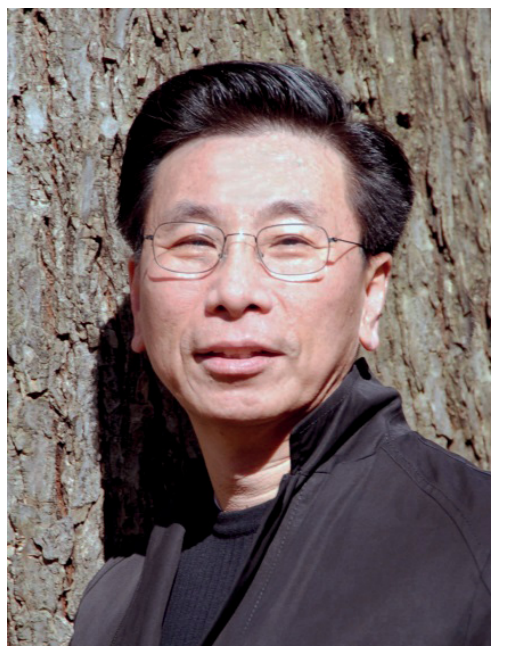

Photo 1. Ge Gan-ru, photo by Philip Li-fu Tsai

in the sense of trying to do something "never heard before." That second kind of originality can lead a person, perhaps even without knowing it, to be insincere: to make compositional decisions not on the basis of honesty, but rather by calculating how to do things which will shock an audience, and get publicity. I'm not interested in that kind of "originality."

What happened was this: around end of 1982, I had a conceptual breakthrough, as I was comparing differences in Western and Chinese music based on what are considered the four most basic elements in music: pitch, rhythm, timbre and dynamic.

I found that in Western music precise pitch and the precise relationships between pitches are of paramount importance. But in Chinese music, what is more meaningful is how to play a particular pitch: for example, a note is often played with microtonal shadings, alterations of timbre during a note, and also many other ways of decorated it. All this makes for a rich content within any single note, and that is one of major elements making Chinese music uniquely what it is. 
In Western music, rhythm - and meter - is measurable. For example the meters of $2 / 4,3 / 4,6 / 8$. That is because in Western languages, there is a clear sense of accent, and these form different rhythmic patterns in how syllables fall, and how they relate to each other. But in Chinese music, rhythm is often without measure. A good example is a pattern that is popular and very typical in Peking Opera, in which there is a gradual acceleration from slow to fast in a given period of time - without a decision, beforehand, as to how many notes will be needed during that period. It is determined by feeling. It is a pattern that is strongly rhythmic - because each note is accented but it can't be measured, or notated in fixed mathematical proportions. Moreover, it isn't "metric" in the sense of $2 / 4$, etc. Meter relies on the contrast of accent and non-accent and in this pattern everything is accented!
Timbre, too, is approached differently in Chinese and Western cultures. Instrument making in the West is based on the principles of physics; this is not the case in the making of Chinese instruments. If we compare the guitar with the pipa, each plucking instruments, the guitar's body is hollow so that the strings can resonate well, and create purity of tone - in keeping with the principles of physics. By contrast, the body of the pipa is very much like a piece of solid wood. To a Western ear, the sound of pipa can seem to contain more noise than tone.

Thinking these things over, an idea suddenly came to my mind. Why not write a piece with all the characteristics of Chinese music while avoiding those of Western music - yet employing a Western instrument. Yi Feng was the result.
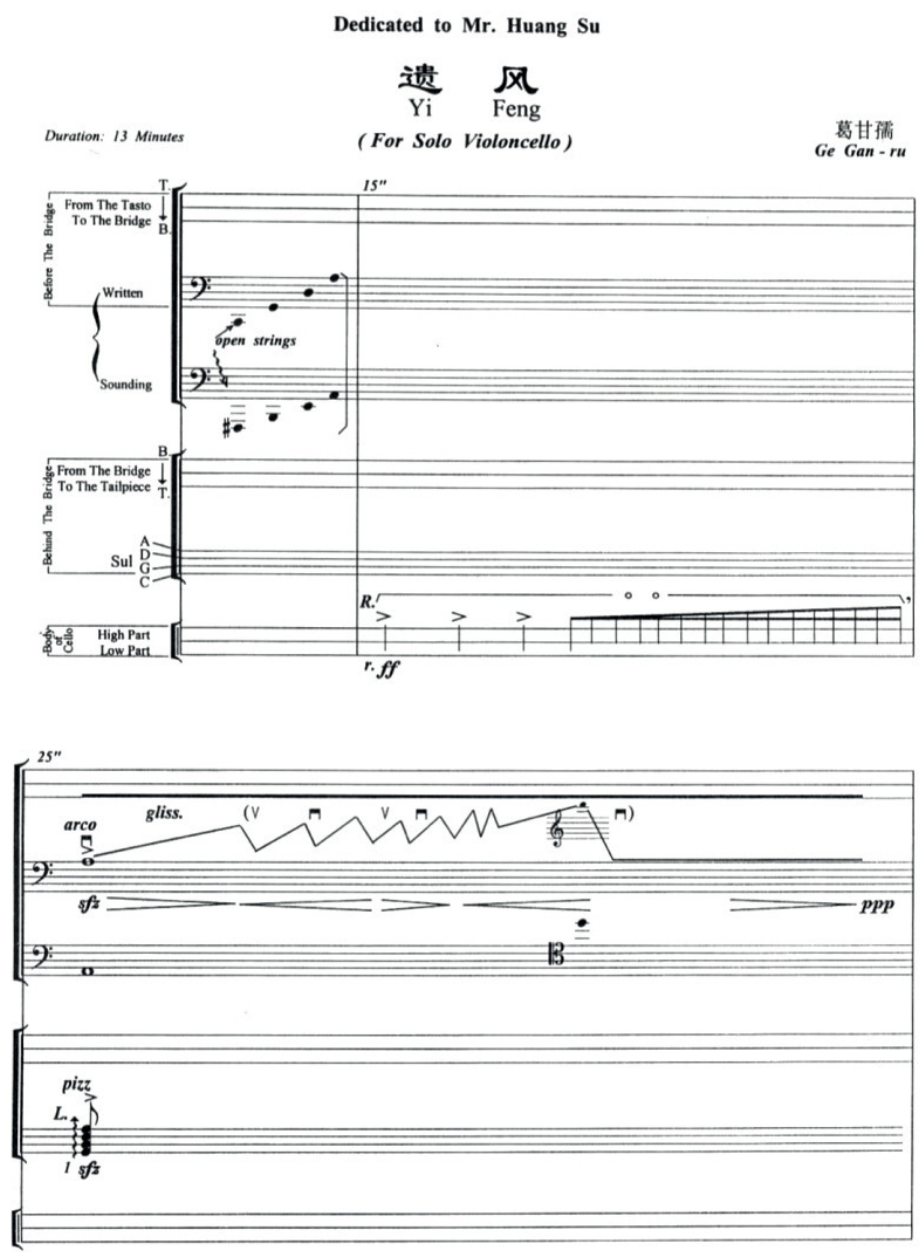

Score of Yi Feng (Lost Style), Copyright 1983 
I used a cello and tuned the strings an octave lower than usual - which made the strings unable to interact with the body of the instrument in a way that created the expected kind of precise, resonant tone which is foundational for Western music. Further, the strings were tuned in fourths instead of fifths. In the piece, the measurable rhythmic patterns were avoided as well. Moreover, I treated the cello as an ensemble of different instruments: the player is asked to play on every part of the instrument. Madeleine Shapiro at the American Festival of Microtonal

Music, Church of St. Luke in the Fields, NYC, May 15, 2010:
This piece made me feel for the first time that I came close to the sound ideal I had been looking for. Yi Feng was written for and premiered by Frank Su Huang. The premiere came at a sensitive time politically: China was still under the influences of the Cultural Revolution. Audiences were not prepared for the unconventional sound of the piece, and I was sharply criticized for my individualism. Conformity was expected at that time. Chinese music was supposed to sound "traditional," and Western music was supposed to sound "traditionally Western." I was doing something that the critics didn't know how to categorize.

https://youtu.be/XvvffLhNTtU

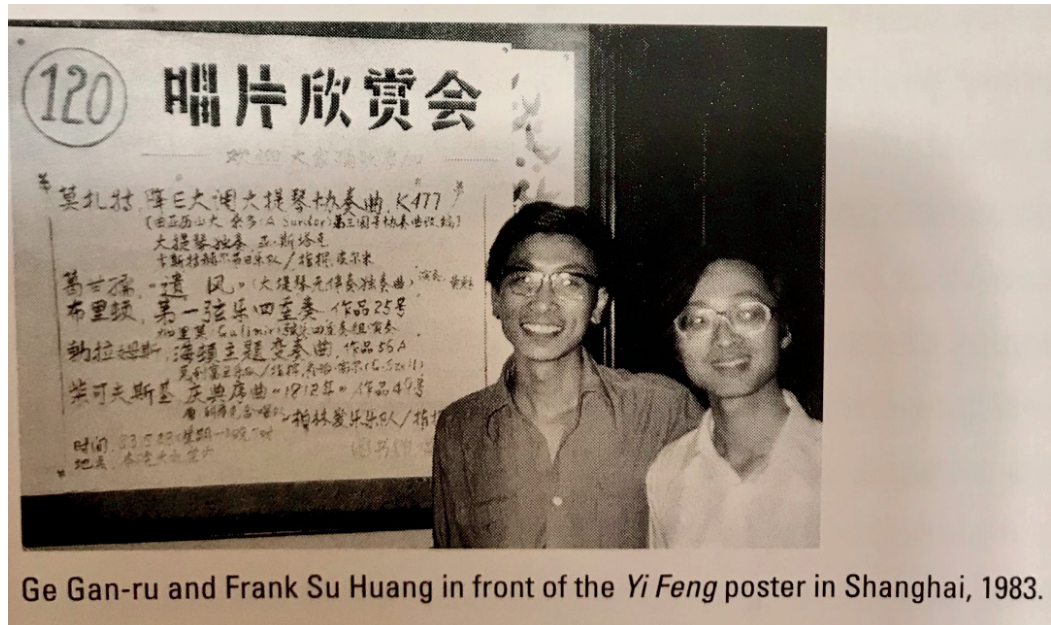

Photo 2. Ge Gan-ru and Frank Su Huang in front

of the Yi Feng poster at Shanghai Conservatory of Music, 1983

Edward Green: How did growing up in China - including during the period of the Cultural Revolution - affect you? Specifically in your decision to become a composer?

Ge Gan-ru: My musical life began with the violin. I began to study it when I was quite young. In fact, I never thought at first of becoming a professional musician at all, let alone a composer. The Cultural Revolution started when I was 11 (I was born in 1954). All the schools were closed. Practicing violin at home was the only thing I could do. When I was 17 , I was sent to a labor camp on an island near my hometown of Shanghai to receive what was called re-education. Pretty much everyone, the government thought, needed it!

My violin study was abruptly interrupted. Every day we were forced to work in the rice fields from dawn to dust. My fingers were completely numbed after a whole day's labor. On top of that, I couldn't find any place to practice my violin. About ten young laborers shared a small room. When everyone was exhausted after a long day of work, who could tolerate the sound of someone practicing the violin?

But, as can happen sometimes, even in the most hopeless of situations, miracle can occur. First, a man in charge of the irrigation 
station offered me a place there to practice violin after my work in the fields, far away from my dorm - in the middle of nowhere, surrounded by vast rice fields. Nobody could hear my practice. It took me about 45 minutes to walk there - and there were no roads. I walked there every night in darkness, rainy nights or dry, no matter how tired I was after laboring in the rice fields earlier. I will never forget the joy approaching that place because I could be alone with music. I said to myself, I would be content forever if I could keep practicing at this place - for the rest of my life, even! That's how happy I felt. Years later, I realized what had happened: music unconsciously had become my reliance during the darkest period of my life. One of the darkest periods, too, it must be said, in chinese history.

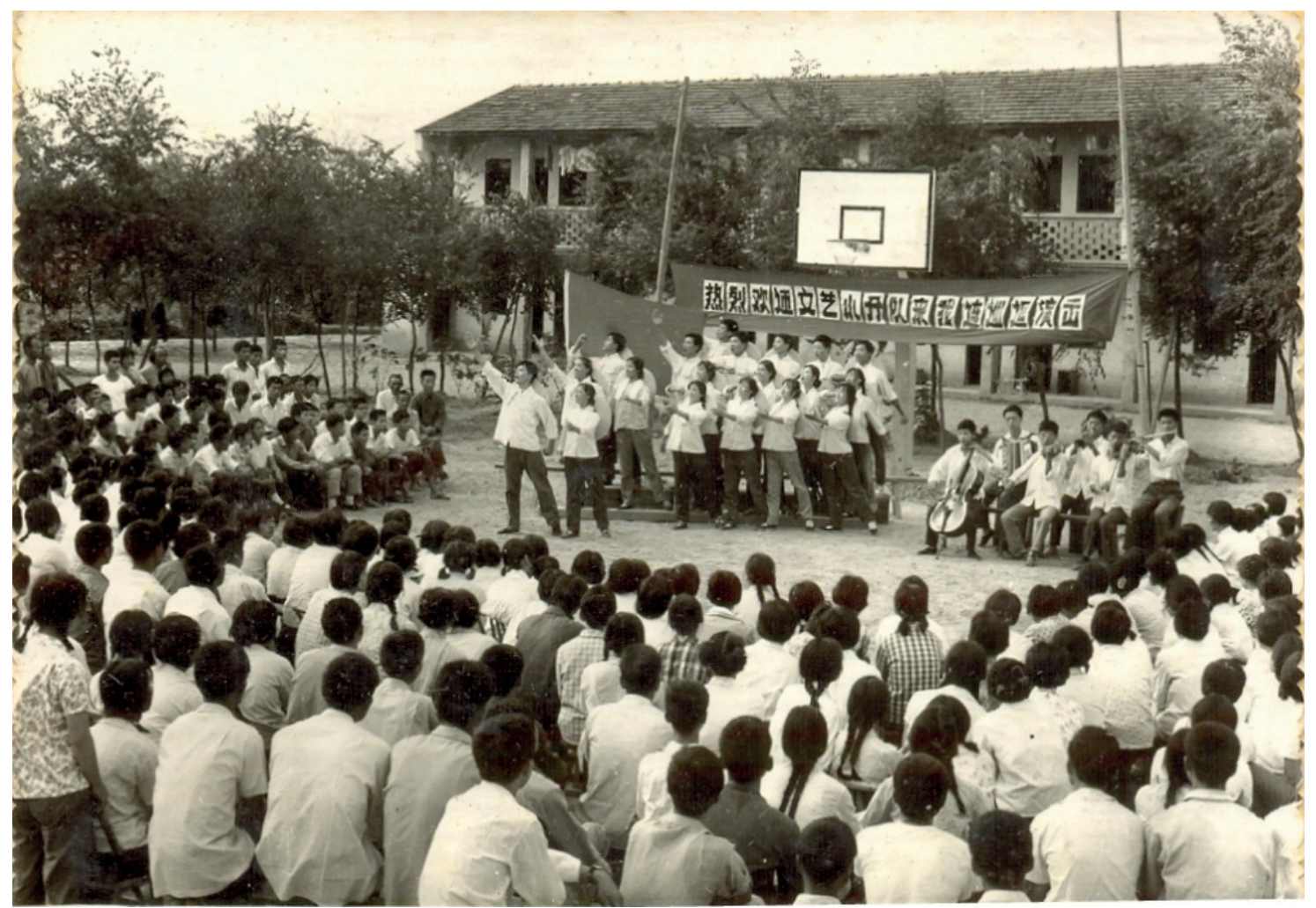

Photo 3. A touring performance in Changjiang Camp, Chongming Island, Shanghai, China, 1973. Ge Gan-ru is the 1st violist in the front row on the right

Another lucky thing that happened was that I met at the camp one of the best violin teachers from Shanghai who was also sent there for "political reeducation." We formed a special bond. He gave me lessons twice a week even as I had no money to pay him. Instead, I tried to help him in other ways.

Life was very hard and boring in the camp. So the government organized an ensemble for providing entertainment to the laborers. My teacher was appointed as a supervisor of the ensemble and he brought me into it. It was an odd ensemble! - with a strange even illogical, mixture of Western and Chinese instruments. Meanwhile, we were only allowed to play revolutionary music, music for propaganda purpose.

I didn't like the purpose of the ensemble, but I did have a great interest in it, in terms of adapting and arranging music for the ensemble, despite my lack of any real training in music theory at the time. This was the first step in my becoming a composer.

Edward Green: In your work you often seem to take a delight in showing surprising, even strange new ways of dealing with instruments. Is this true? And yet you are not a composer who is interested in shocking 
audiences; you have talked often about how important it is to you to be sincere in everything you write - and you did so again at the very beginning of this interview. Can you talk about the relation of these things?

Ge Gan-ru: Yes; definitely: I have never purposely tried to shock audiences through my music. On the contrary, I always try to avoid using superficial or exotic effects as a means of "winning" an audience. What I have been trying to do is to write the music that's in my heart and let the chips fall where they may, without compromises. That's my understanding of sincerity. I find the more sincere I am in composing, the more original my music will be - without any conscious straining after it.

I have not composed for traditional Chinese instruments, except one work. I feel mixing traditional Chinese instruments with Western instruments could be a cheap or simplistic way to lure audiences. It would be like Cha - a mixture of tea and coffee. Some people like it; not me! But returning to music directly: I believe a composer's ultimate duty is to be able to express his or her finest musical feelings, the feelings so-tospeak under his or her own skin. Superficial exotic sound effects will never make genuine music. The finest feelings are the final result of the digestion of everything we experience and absorb in our life.

Using Yi Feng as an example. When I was composing it, my purpose was not to write an avant-garde piece. My goal was to find a way in which I would feel conformable to express my musical feelings. It turned out to be the piece it was. So be it!

Edward Green: Could you compare your experiences studying music in China, and then at Columbia University?

Ge Gan-ru: It's hard to do! It all depends on the stage of one's life and the state of one's musical progress is. I always have a special feeling towards the Shanghai Conservatory of Music because my admission to the conservatory changed my life. Nothing was more dramatic in my life than the change from labor camp to that conservatory.

I studied violin there for three years and composition for four years. After graduation,
I was appointed an assistant professor of composition. The study in the conservatory provided me with much practical experience, such as playing in the conservatory's orchestra, as well as ample opportunity to write music for schoolmates who could play my music back to me immediately — which is so important for a young composer. Not to write "in the abstract," but to hear the actual sonic impact of the notes one puts on the page!

The time when I was there was very particular. The Cultural Revolution was almost over and the political atmosphere was, thankfully, loosening. After many years of chaos, teachers and students finally had the opportunity to catch up with their studies, and increase their knowledge. Everyone worked hard to make up for lost time. We were hungry for information about developments in music outside of China. Bit by bit, we had chance to listen to examples of the "New Music," such as European and American twelve-tone music, and the unusual new approaches taken by people like John Cage, George Crumb, and Toru Takemitsu.

I was very fortunate to have, as my composition teacher, Prof. Chen Gang. He is the co-composer of the very famous "Butterfly" violin concerto. His knowledge of traditional Western music was deep; at the same time he not only encouraged me to try the new, modern techniques but he also studied them himself. He was a very good teacher.

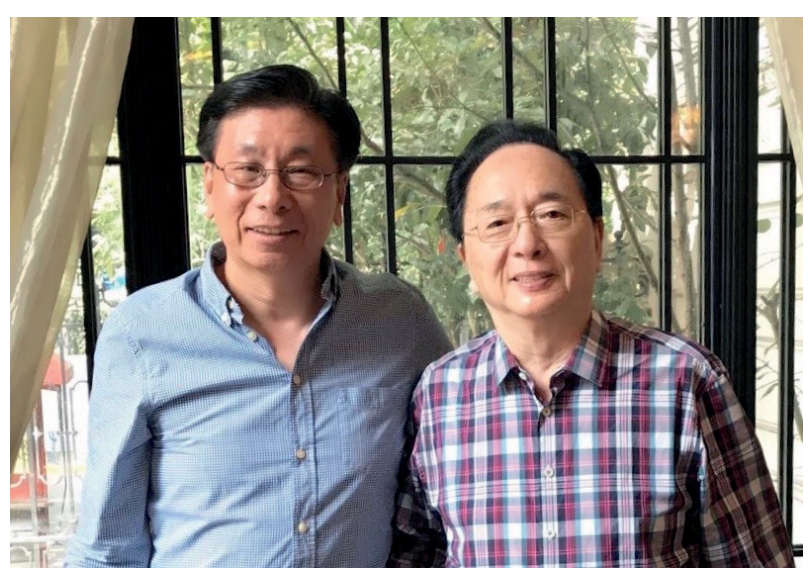

Photo 4. Ge Gan-ru and his teacher,

Prof. Chen Gang in Shanghai, Chine, October 2017 
So I had fine training and education at Shanghai Conservatory. I had already composed Yi Feng and my first string quartet, and when - through the remarkable work of Dr. Chou Wen-Chung - I learned of the possibility to advance my study at the Columbia University in New York, where he taught, and was invited to apply, and was accepted, I was bursting with eagerness to go!

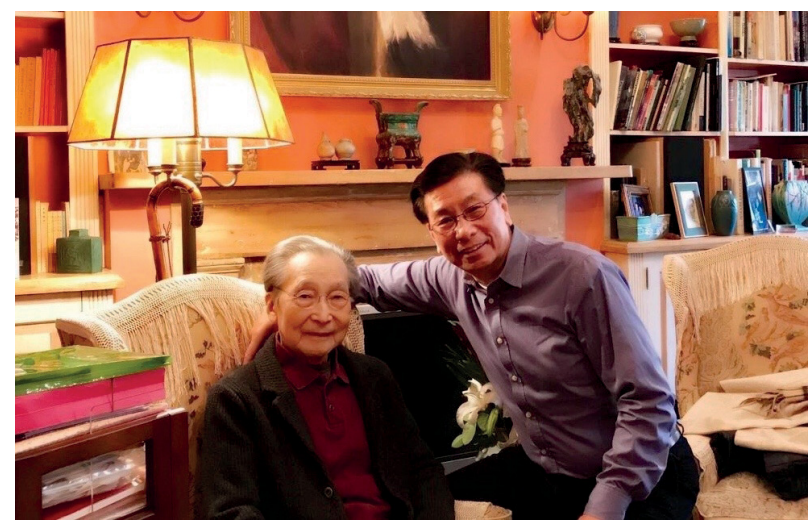

Photo 5. Ge Gan-ru visits his teacher,

Prof. Chou Wen-chung in NYC, November 2017. Photo by Vivian Wanhe Ge

What a dream it was. But, oh, how that dream was shattered upon arriving in New York. First, there were financial difficulties. Although I had a full scholarship to pay the tuition, I had to work in restaurant at night to cover my living expenses. Also, the composition department at Columbia was totally different from that of Shanghai Conservatory. The school has only compositional students and no performing majors. There were only a few pianos in the department. I had to make an appointment to use one.

What I didn't expect was the conservative academic atmosphere. Before I came to Columbia, my biggest expectation was I could finally be free to compose whatever I wanted. But, almost all of my theory classes were about 12 tone and serial music - ways of making music I had already practiced heavily and given up finally when I was in China. I also found that no one understood and cared about my music although I wrote some of my better compositions then such as $G u$ Yue (Ancient Music), $W u$ for piano and orchestra, and Chinese Rhapsody - which is scored for Orchestra.
Ricardo Descalzo plays

the Gong movement from

Gu Yue (Ancient Music) in Alicante, Spain, October, 2013:

https://youtu.be/xSVSW2ErOJU

To be honest, I was depressed and confused. Eventually I managed to get my doctoral degree, but the emotional scar was with me for a long time. I don't mean to blame Columbia. It is because it was a wrong time in terms of my own music development.

Edward Green: As a violinist, can you say something about your chamber music for strings? In particular, your string quartets?

Ge Gan-ru: Well, of course, I am familiar with violin and string instruments inside and out. I believe if I were not a violin player, I would not have been able to write my string quartets in just the way I did from the inside, so-to-speak. They require many "extended techniques." But I always tell myself, these techniques are only tools, they are not the music, itself. They only become music when they are applied with a clear emotional purpose.

For instance, at the beginning of my Fifth String Quartet, which I titled "Fall of Baghdad," I tried to express the desperate screaming I felt - and certainly the people there felt - about the Gulf War. The extended technique of pressing the bow to play on the strings behind the bridge could be the best and most appropriate way to produce that kind of raw feeling.

Modern Works plays "Fall of Baghdad," 2008:

https://youtu.be/y1QhJ_b7egw

Also, at the end of the second movement, I used col legno on the strings - but behind the bridge - to produce a drum-like effect.

In the weeping section of the third movement, I wrote a melody for the first violin with lots of glissandi which, I believe, genuinely expresses the extreme pain.

Strangely, with all what I have done with the violin, I have not composed something for solo violin with piano or with orchestra. Maybe it's because I am so familiar with the violin repertoire that it becomes a burden for me - a difficulty in imagining something authentically different. I am not a pianist but I have written a 
good deal for that instrument: solo music; also a piano quintet and a piano concerto.

Edward Green: What composers, both contemporary and of earlier music history, do you admire the most? And, of course, why?

Ge Gan-ru: I love the music of the old Masters! But, if I have to choose, I would say I feel Bach and Mendelssohn's music affects me the most deeply. I particular appreciate their impeccable ability to hear! Personally, I think that is one of the main reasons why their music sounds so natural and smooth.

I also love some newer composers like Debussy, Stravinsky and Gershwin. I am amazed by their unprecedented, yet unmistakably identifiable music languages. It seems they knew from day one what their music should sound like without struggling. With that advantage, they have a total freedom to compose whatever way they want. These are true music geniuses.

Edward Green: What are your most recent compositions? And what are you planning to create next?

Ge Gan-ru: Three months ago I finished revising my Twelve Preludes for Piano which I initially composed 40 years ago. The revisions were premiered by Yiming Zhang, a rising star specializing contemporary piano music, in Guangzhou \& Sanya, China in July and they will be recorded by him in December for Grand Piano, a label under Naxos.

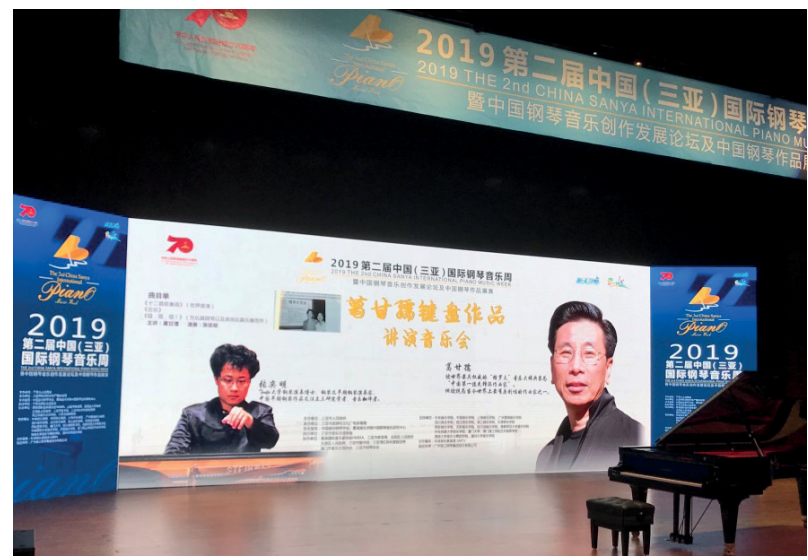

Photo 6. The stage before Yiming Zhang's recital of all Ge Gan-ru's piano music at the 2nd China Sanya International Piano Music Week, 2019
I am currently working on Twentyfour Etudes for Inside Piano - something I've had in my mind for many years. They will be premiered also by Yiming Zhang, at the Xinghai Conservatory of Music in Guangzhou, China in April 2020.

Here is the history to this: over the years, I have written several works for inside piano that is, music directly for the strings, without needing the fingers on the keyboard to engage the hammers. What I found is that, although these techniques had been employed by composers over a century, they had not been systematically studied and categorized. My etudes are designed to create - in an artistic way - that kind of systematic structure.

If we look at the history of the piano, today's piano developed from some kind of keyless plucking instrument in the distant past. The keyboard came later. While the many, many possibilities of the keyboard have been explored - just to mention Liszt, Chopin, Bartok, and, of course, techniques of jazz piano - the vast potential of the inside of the piano was unexplored until the 20th century. It will be wonderful if one day this vast part of the instrument can also be fully utilized. How much fun would we have then? To me, this is a logical, inevitable evolution of the piano.

The other significant fact is this: the overall sonority inside the piano is similar to the sonority of Chinese instruments. Sound inside the piano creates in me a lot of imaginative ideas; new possibilities of music making. I hope these pieces will not only be the material for future pianists to learn varies extended techniques inside the piano, but might also become regular concert music.

After working on the etudes, I plan to revise my large orchestral piece Ghost Suite which was commissioned and premiered by the Shanghai Philharmonic in 2013. I should be able to make it a better piece!

Edward Green: One of your most surprising pieces is Wrong, Wrong, Wrong, which is based, I gather, on a famous Chinese poem. Can you tell us about this piece? I don't think there's anything quite like it in the history of solo vocal music.

Ge Gan-ru: I wrote it for the avant-garde pianist, Margaret Leng Tan in 2006. She had 
asked me for a toy piano piece but I had no interest in that. Or so I thought! In 2004, she recorded my piano concerto with the Royal Scottish National Orchestra. Because of the tight budget, she agreed to a fee lower than what she wished for, on one condition: that I write a short, 3 to 4 minute toy piano piece for her later. So, you see, I had no choice!

In the next two years, however, she never mentioned this and I thought she had forgotten about it. Then one day she called and said "Gan-ru, you still owe me that piece." So, of course, I needed to fulfill my obligation, but I still had no idea what to write. She insisted on bringing her grand toy piano and leaving it at my home. I felt it was really unnecessary because I didn't see anything special about a toy piano except a much narrower register.

I played it occasionally, only for the reason that it looked cute. However, gradually, I started to be attracted by its distinctive timbre. In the meantime, Margaret was sending me more toy instruments. She actually had a full orchestra of them.

Then one day, when I was reading the poem “Wrong, Wrong, Wrong!" by Lu You, a famous poet in China in the 12th century - and an idea suddenly struck me: Why not write a piece for a recitation of the poem by a pianist, self-accompanied by a toy ensemble?

The poem is about Lu You himself, who was forced by his mother to divorce his wife, Tan Wan, also a talented poet. One day, years after the divorce, Lu You accidentally met his ex-wife in a garden. After the encounter, he was so remorseful that he wrote the poem, with the deepest sorrow, on the wall of the garden. After Tan Wan had a chance to read it, she, in turn, with devastation, wrote a poem in response: "Hard, Hard, Hard!"

So I wrote "Wrong, Wrong, Wrong!" and paid off my debt. In 2009, I composed a sequel "Hard, Hard, Hard!" with the same instrumentation, commissioned by pianists Yen-lin Goh and Genevieve Lee.

Both pieces will be on my upcoming CD along with my 12 Preludes played by Yiming Zhang.

Edward Green: Do you have an overall philosophy of music, and of musical

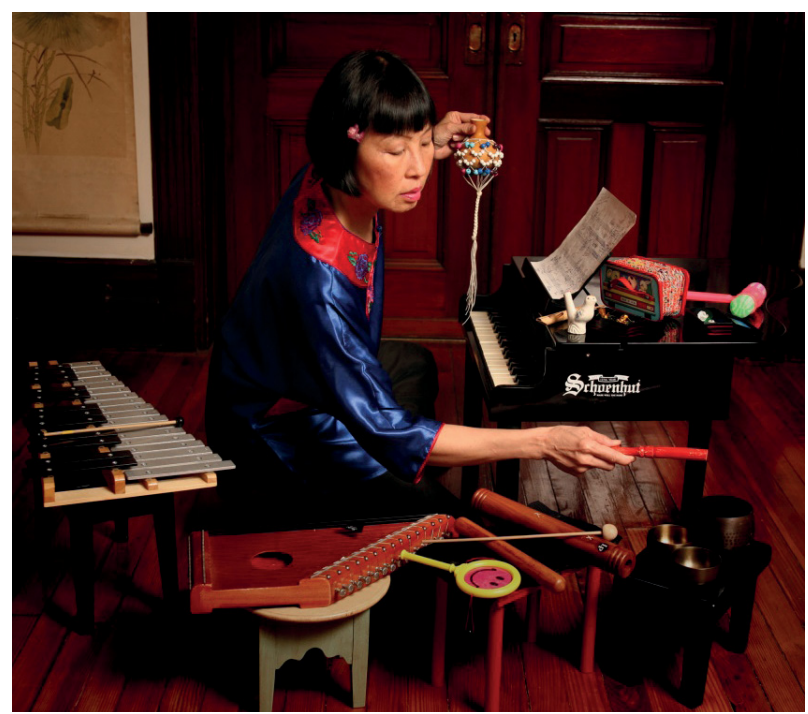

Photo 7. Margaret Leng Tan plays

Wrong, Wrong, Wrong!

Photo by Michael Dames

composition? Is it related, perhaps, to a large philosophy of art and of life?

Ge Gan-ru: No, actually, I don't. I feel I should separate music from words, literature, philosophy and any other art form. However, here I may try to talk about some of my concerns as a composer.

Since day one, when I became a composition student at Shanghai Conservatory, I had been very conscious - even obsessed - about how to find my own artistic voice. I believe it is the make or break issue for being a composer. That is, being true to oneself, and creating music that reflects that. All other aspects of music are secondary. Otherwise, how could I create genuine music? How could I express my feelings by using the language of other composers? To me, it is against the very principle of being a composer.

It is easy to understand the principle, but hard to apply it in practice. As a young composer, after much effort resulting in failure, I was depressed. There was a time I felt unlucky. That is, as a composer from China. In Western music, before Mozart there was Haydn. At least, Mozart could get a clue from Haydn's music, a starting point in terms of forming his own compositional style. But for me, I had no one to model from. I wanted to be a Chinese concert composer! But where was my starting point? 
I faced a cultural conflict. I couldn't reconcile the fact that I had Chinese music in my blood, while I was systematically trained in Western music and adored it. The idea of an individual musical voice is not in the Chinese musical tradition. Most Chinese music is not composed by any individual composer; rather, it is inherited, having evolved through generations. Therefore, a Chinese audience appreciates music in a different way from a Western audience. Chinese audiences appreciate Chinese musical characteristics but not the individual language or style of a particular creator of that music. This is not because Chinese people don't know how to appreciate the individualism in arts. Chinese people are extremely sensitive to individuality in Chinese poetry and calligraphy. The way they enjoy Li Po's poem is the same as the Western people enjoy Beethoven's music. But, surprisingly, this was just not so when it came to Chinese music.

The odds I was facing, thus, were - as I saw it - enormous. Even with the break I achieved with Yi Feng, I realized it was more or less a singular thing: a conceptual piece. How could I sustain that conceptual breakthrough, yet not repeat myself in future works?

I also tried to focus on practical ways to improve my composing. There are so many compositional methods, but if we are not careful, these could all become traps and, once composers are in them, it can be hard to get out.

One thing I have been doing is this: I try to hold my thoughts for a new piece for as long as I can before actually putting something down on the page. During this waiting period, I will see if my original passion lasts. Any short-lived musical idea is not worth efforts. Take my orchestral piece Shanghai Reminiscences as an example. I had the idea for over twenty years. In the end, I felt I would die if I didn't compose the piece! And that feeling - of a kind of beautiful, sincere desperation to give birth to something - I believe signals a promising work.

Another thing I have been doing is this: in order to strengthen my individual voice, to have the ability completely and precisely to transfer what I am hearing inwardly onto the score. It took me a long time to gradually improve that ability. Let me be honest: in the beginning, the accuracy was only about 5\%. Gradually it increased. After years of practice, I feel the gap between my inner hearing and the music on score is getting much smaller and I am able to express my feelings far more precisely.

Edward Green: If you were asked the impossible question - that is, ifyou were asked to choose among your many works in order to say, "This work most deeply and successfully expresses who I am, and what I want to say through music" - what would your answer be?

Ge Gan-ru: I might choose these.

Yi Feng (Lost Style) for Solo Cello without accompaniment (1983) performed by Frank Su Huang ("Lost Style.” New Albion Records. $\mathrm{N}-134)$

Gu Yue (Ancient Music) — Four Pieces for Prepared Piano (1985) performed by Margaret Leng Tan ("Sonic Encounters." Mode Records, 15)

Wrong, Wrong, Wrong! for Voice, selfaccompanied by a Toy Orchestra (2006) performed by Margaret Leng Tan ("Lost Style.” New Albion Records, N-134)

Fall of Baghdad - Fifth String Quartet (2007) performed by ModernWorks ("Fall of Baghdad.” Naxos Records 8.570603)

Shanghai Reminiscences for Orchestra (2009) performed by the Royal Scottish National Orchestra, conducted by Tsung Yeh. ("Shanghai Reminiscences." Naxos Records, 8.570609)

Edward Green: Thank you for this fine interview!

Ge Gan-ru: You are very welcome.

About the author:

Edward Green, Ph.D. (New York University), Composer, Professor in the Department of Music History, Manhattan School of Music, ORCID: 0000-0002-7643-1187, edgreenmusic@gmail.com 